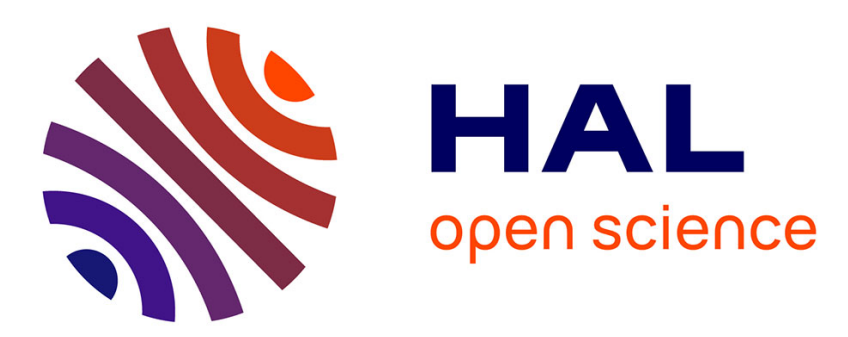

\title{
The Chemistry of Retinal Transplantation: The influence of polymer scaffold properties on retinal cell adhesion and control.
}

Andrew John Treharne, Martin Christopher Grossel, Andrew John Lotery, Heather Anne Jane Thomson

\section{To cite this version:}

Andrew John Treharne, Martin Christopher Grossel, Andrew John Lotery, Heather Anne Jane Thomson. The Chemistry of Retinal Transplantation: The influence of polymer scaffold properties on retinal cell adhesion and control.. British Journal of Ophthalmology, 2010, 95 (6), pp.768. 10.1136/bjo.2010.184002 . hal-00595934

\section{HAL Id: hal-00595934 \\ https://hal.science/hal-00595934}

Submitted on 26 May 2011

HAL is a multi-disciplinary open access archive for the deposit and dissemination of scientific research documents, whether they are published or not. The documents may come from teaching and research institutions in France or abroad, or from public or private research centers.
L'archive ouverte pluridisciplinaire HAL, est destinée au dépôt et à la diffusion de documents scientifiques de niveau recherche, publiés ou non, émanant des établissements d'enseignement et de recherche français ou étrangers, des laboratoires publics ou privés. 
The Chemistry of Retinal Transplantation: The influence of polymer scaffold properties on retinal cell adhesion and control.

\author{
Andrew J. Treharne, ${ }^{1}$ Martin C. Grossel, ${ }^{1}$ Andrew J. Lotery, ${ }^{2,3}$ Heather A. Thomson. ${ }^{2}$ \\ ${ }^{1}$ School of Chemistry, University of Southampton, Southampton, SO17 1BJ, UK \\ ${ }^{2}$ Clinical Neurosciences Division, School of Medicine, University of Southampton, \\ Southampton General Hospital, Southampton, SO16 6YD, UK \\ ${ }^{3}$ Southampton Eye Unit, Southampton General Hospital, Southampton, SO16 6YD, UK
}

\title{
Correspondence to
}

Prof. Andrew Lotery, Clinical Neurosciences Division, Mailpoint 806, Southampton General Hospital, Southampton, SO16 6YD, UK;

Email: a.j.lotery@soton.ac.uk

Tel: +44 (0) 2380794590

Fax: +44 (0) 2380794120

Key Words: Retinal Pigment Epithelium, Transplantation, Retinal Degeneration, Biomaterials, Cell Adhesion

Word Count: 2638

\begin{abstract}
Age-related macular degeneration (AMD) is the most common cause of blindness in the United Kingdom. Cellular replacement of retinal pigment epithelium (RPE) cells, is a potential therapeutic option to treat the cellular loss and dysfunction which is characteristic of AMD and other progressive retinopathies. A supportive scaffold, natural or artificial, may be required to facilitate cell delivery to the eye. Research to improve the biomimetic properties of such scaffolds, in order to optimise cell attachment and functionality following implantation, is ongoing. This short review will focus on the potential of biomaterials for ocular tissue engineering and how surface modification and the physical properties of these scaffolds can be tailored to help realise the full clinical potential of RPE cell transplantation.
\end{abstract}




\section{Background}

Despite differing aetiology and pathology, degenerative retinal diseases including age related macular degeneration (AMD) and retinitis pigmentosa (RP) culminate in photoreceptor cell death. Loss or damage to the retinal pigment epithelium (RPE) is also a common feature of these somewhat disparate conditions. [1,2] Currently no treatments are known to halt or reverse this cellular loss. Recent advances in gene therapy for degenerative retinal diseases have shown promise in both animal models [3-5] and clinical trials. [6-8] However, longterm safety and efficacy of gene replacement therapy is yet to be established. In addition the effectiveness of such treatments will be somewhat limited in patients with advanced retinal degeneration, as a result of significant pre-existing cell loss. Thus treatments which aim to replace dystrophic cells are desirable either alone or as an adjunct to gene therapy.

\section{Transplantation and the retina}

Positive outcome of cell transplantation studies in animal models, such as the Royal College of Surgeons rat (RCS), have paved the way for human studies. [9-11] Some efficacy has been demonstrated with transplantation of healthy photoreceptors, $[12,13]$ sheets of foetal neuroretina [14-16] and donor iris pigment epithelium tissue.[17-19] In particular transplantation or translocation of RPE cells with or without choroid has shown promise. [20-22] Autologous RPE transplantation can in principle restore vision, by supporting photoreceptor cell function. However surgical complications remain high and visual improvement so far has been limited.[23,24] Thus stem cells and/or progenitor cells are being assessed as alternative sources of cells for transplantation.

\section{Stem cell transplantation}

Stem cells are typically described as undifferentiated cells which are capable of self-renewal and have the ability to give rise to one or more differentiated cell types. [25] Within the adult eye there are several areas which harbour progenitor cell populations including the ciliary margin of the retina,[26-28] the iris pigment epithelium [28-30] and Müller cells.[31-33] These progenitor cells have been shown to differentiate into a range of neuronal, glial and retinal specific cell types following maintenance in a conducive in vitro environment. It is this obligate requirement for complex cellular interactions and often limited self renewal capacity in vitro which defines these as progenitor cells rather than stem cells.[34] Stem cell therapy to repair and regenerate the corneal epithelium has been successfully employed clinically for a number of years.[35] Retinal cell replacement however remains 
elusive. To date, a number of studies have investigated various stem cell types as potential sources for retinal transplantation including embryonic stem cells (ESCs), adult stem/progenitor cells and more recently induced pluripotent stem cells (iPS).[36-38]

Results have been encouraging. Following differentiation into retinal pigment epithelium cells in vitro, subretinally transplanted ESCs have led to improvements in visual acuity. $[39,40]$ In addition, human iPS cells have been differentiated towards functional RPE cells. This has resulted in short-term survival and maintenance of photoreceptor cells following transplantation into the RCS rat model.[41] Despite these apparently positive findings, efficiency of cell delivery and degree of visual rescue often remain unsatisfactory. This lack of efficacy may be due to a number of reasons for example, RPE cells are anchorage dependent and therefore must quickly (re)attach to an accommodating matrix following transplantation. Bruch's membrane (BM), the inner most layer of the choroid, is the supportive structure upon which RPE cells are normally attached. However, in advanced retinal disease, with age or following macular surgery the basal lamina layer of BM may be damaged or absent.[42] Thus, it is difficult for newly transplanted cells to attach in such a non-permissive environment. Transplanted cells may therefore undergo anoikis, or cells may clump together rather than forming appropriately polarised cell monolayers. Lack of cell to cell contact may also lead to transition of RPE cells to inappropriate phenotypes. [43]

Use of stem cells for retinal repair holds enormous promise for generation of sufficient appropriate cell populations for transplantation, due to their proliferative nature and ability to give rise to multiple cell types. The gap between theory and clinical exploitation however remains considerable.[44] Significant challenges remain both from a basic biology and practical application standpoint. Principal among which is identification and use of cell sources which are viable, karyotypically stable and which will yield sufficient cell numbers.[45] The ability to isolate an homogenous, mature population of cells for transplantation is also vitally important to avoid the possibility of teratoma formation, especially when using embryonic derived cell sources. Safe and efficient tissue delivery also needs to be considered, as does survival and integration of the transplanted cells within the host. [28,46,47] Any transplanted material must also be capable of maintaining an appropriate state of differentiation in vivo. In addition immune surveillance is a significant issue, thus autologous sources of cells for transplantation, to negate problems with graft rejection, would be the ideal.[48] 


\section{Cell delivery scaffolds}

In this review we aim to discuss how substrates can be tailored to enhance retinal cell attachment and viability for transplantation. It has been documented that cells in suspension have a lower immune privilege than those delivered as an intact sheet.[48] Furthermore cells injected as a suspension often fail to regain a fully differentiated phenotype.[49,50] In addition, the viability of RPE cells delivered to the subretinal space is often dependent on the integrity of the underlying substrate: Bruch's membrane.[51,52] Thus it may be prudent to transplant sheets of cells rather than suspensions of single cells or cell aggregates. Many techniques and devices are being developed to improve the delivery and survival of transplanted cells, one such being the use of scaffolds for cell attachment and growth prior to transplantation. Natural scaffold materials have been investigated including Descemet's membranes, [53] lens capsules [54,55] and amniotic membranes.[56,57] Synthetic polymeric biomaterials have also been utilised as cell delivery vehicles for retinal cell types as detailed in Table 1.

\section{Biomaterials and the eye}

Young and co-workers demonstrated that use of a polymer scaffold for stem cell delivery to the subretinal space presented advantages over simple injection of cell suspensions.[58]. When a suspension of cells was injected into the eye, problems such as immune response, disorganisation of cells and cell death were encountered. However, when a scaffold made of biodegradable polyester was used, cell survival and organisation were improved. There was also evidence that the scaffold promoted differentiation of the retinal progenitor cells towards mature retinal cell phenotypes.[58] Poly (L-lactic acid) (PLLA) and poly (D,L-lactic-coglycolic acid) (PLGA) were used in this investigation. These polymers were selected as they are biocompatible, easily processable and have been successfully used for tissue engineering applications such as bladder substitution [59] and bone tissue regeneration.[60] The degradation rate of these polymers can also be manipulated by changing properties such as molecular weight and the ratio of lactic to glycolic units. Thus polymers can be designed to degrade over the most appropriate timescale for the desired application. 
Aside from PLLA and PLGA, several different polymers and preparation techniques have been investigated in the search for a polymer with suitable biocompatible and mechanical properties to be employed as a cellular scaffold in the eye. Many factors such as surface chemistry, mechanical properties and surface topology can affect the usefulness of different materials for cell attachment and survival. Poly(methyl methacrylate) (PMMA) has been used to manufacture ultra-thin, micro-machined scaffolds for retinal progenitor cells (RPCs).[61] Murine RPCs isolated from enhanced green fluorescent protein positive (GFP+) transgenic mice (C57BL/6 background) were shown to grow and differentiate well on these scaffolds both in vitro and in wild-type C57BL/6 mice. Similarly, poly(glycerol sebacate) (PGS) [62] has been used to manufacture a porous, elastic scaffold and poly( $\varepsilon$-caprolactone) (PCL) [63] to produce ultra-thin nanowire scaffolds. Again, successful growth of murine RPCs was shown both in vitro and wild-type and degenerative mouse models. Both types of scaffold were coated with laminin prior to cell seeding. Laminin is an extracellular matrix (ECM) protein which can aid the survival of transplanted cells by mimicking their natural environment. It was shown that, in culture expression of mature bipolar and photoreceptor cell markers such as rhodopsin, recoverin and PKC $\alpha$ were upregulated on these scaffolds, while several early progenitor markers including Pax6, Hes1, nestin and Sox2 were downregulated. Biodegradable poly(hydroxybutyrate-co-hydroxyvalerate) has been used to manufacture non-porous thin films.[64] These films were modified using an oxygen plasma to generate a more hydrophilic surface. This approach was found to provide a more suitable environment for attachment and growth, of a human RPE cell line, compared to untreated films. Use of an air plasma treatment by Williams et al. was found to increase the surface wettability of commercial poly(urethanes) [65] and poly(dimethylsiloxane) (silicone rubber). [66] These surfaces were found to be well suited to growth of an intact monolayer of RPE cells compared to an untreated surface. Besides synthetic polymers, proteins such as collagen have been manufactured into thin films and shown to be compatible with RPE cells both in vitro and in vivo.[67] However, as the collagen used was derived from equine sources, problems may be encountered at a later stage due to implantation of a non-native protein into the eye. 


\section{Surface modification and tissue engineering}

The influence of surface modification on biomaterial applications has been extensively studied in other fields of tissue engineering (Table 1). The introduction of an amine surface coating, for example, may increase the stability of a biodegradable polymer in the initial stages of degradation. Attempts have been made to use wet chemical and plasma techniques for creating an amine surface layer on PLGA.[68] PLGA has also been treated with ammonia plasma to facilitate collagen attachment for cartilage tissue engineering.[69] A separate study demonstrated that treatment of PGLA with ammonia plasma improves surface roughness thereby providing enhanced attachment of collagen.[70] Poly(urethane) has been surface modified with primary amine groups to facilitate the attachment of ECM molecules producing enhanced murine fibroblast cell attachment and signalling.[71] Nelea et al. [72] were able to show that surface-modifying polypropylene and nylon- 6 with ammonia plasma can inhibit expression of type X collagen in human mesenchymal stem cells (MSCs). This has the potential to produce MSCs of the appropriate phenotype for use in intervertebral disc tissue engineering. Carbon dioxide plasma treatments have been used to improve rodent fibroblast and nerve cell adhesion on PLLA surface.[73] While plasma coating of a PLGA surface with titanium oxide has also been shown to improve surface hydrophilicity for human dermal fibroblast cell adhesion.[74]

Extracellular matrix (ECM) proteins have natural cell adhesion qualities. A number of researchers have investigated chemical attachment of these proteins to the surface of various synthetic polymers. The effects of adhering the ECM protein laminin to the surface of PLGA by chemical and plasma methods have been investigated.[75] In this study using rodent Schwann cells, laminin coating was shown to significantly improve cell attachment and affinity for directing peripheral nerve regeneration. Another approach has been to attach collagen to polyester surfaces to increase human articular chondrocyte cell attachment.[76] There is some evidence, however, that treatment of poly( $\varepsilon$-caprolactone) (PCL) with an air plasma is more effective at improving proliferation of Schwann cells than PCL-collagen scaffolds.[77] 


\begin{tabular}{|c|c|c|c|c|}
\hline Polymer & $\begin{array}{c}\text { Surface } \\
\text { modification }\end{array}$ & Cells used & Cellular response & Reference \\
\hline $\begin{array}{l}\text { Poly(L-lactide)(PLLA)/ } \\
\text { Poly(DL-lactide-co- } \\
\text { glycolide)(PLGA) }\end{array}$ & $\begin{array}{l}\text { Laminin } \\
\text { coating }\end{array}$ & RPCs & Increased cell survival & [58] \\
\hline $\begin{array}{l}\text { Poly(methyl } \\
\text { methacrylate)(PMMA) }\end{array}$ & $\begin{array}{l}\text { Laminin } \\
\text { coating }\end{array}$ & RPCs & Increased cell adherence & [61] \\
\hline $\begin{array}{l}\text { Poly(glycerol-sebacate) } \\
\text { (PGS) }\end{array}$ & $\begin{array}{l}\text { Laminin } \\
\text { coating }\end{array}$ & RPCs & $\begin{array}{l}\text { Differentiation towards } \\
\text { mature retinal neurons }\end{array}$ & [62] \\
\hline \multirow[t]{3}{*}{$\begin{array}{l}\text { Poly(caprolactone) } \\
\text { (PCL) }\end{array}$} & $\begin{array}{l}\text { Laminin } \\
\text { coating }\end{array}$ & RPCs & $\begin{array}{l}\text { Proliferation and } \\
\text { expression of mature } \\
\text { retinal proteins }\end{array}$ & {$[63]$} \\
\hline & Air plasma & Schwann cells & $\begin{array}{l}\text { Increased cell proliferation } \\
\text { compared to PCL-collagen } \\
\text { scaffolds }\end{array}$ & [77] \\
\hline & $\begin{array}{l}\text { Laminin } \\
\text { fragments }\end{array}$ & $\begin{array}{l}\text { Adipose- } \\
\text { derived stem } \\
\text { cells }\end{array}$ & $\begin{array}{l}\text { IKVAV sequence } \\
\text { significantly increased } \\
\text { number of cells bound to } \\
\text { surface }\end{array}$ & [78] \\
\hline $\begin{array}{l}\text { Poly(hydroxybutyrate- } \\
\text { co-hydroxyvalerate) }\end{array}$ & $\begin{array}{l}\text { Oxygen } \\
\text { Plasma }\end{array}$ & $\begin{array}{l}\text { RPE cell line } \\
\text { D407 }\end{array}$ & $\begin{array}{l}\text { More hydrophilic surface } \\
\text { and better adhesion }\end{array}$ & {$[64]$} \\
\hline Poly(urethane) & Air Plasma & ARPE-19 & $\begin{array}{l}\text { Increase surface wetability } \\
\text { resulting in RPE } \\
\text { monolayer growth }\end{array}$ & {$[65]$} \\
\hline Poly(dimethylsiloxane) & Air Plasma & ARPE-19 & $\begin{array}{l}\text { Increase surface wetability } \\
\text { leading to enhanced cell } \\
\text { growth }\end{array}$ & {$[66]$} \\
\hline \multirow[t]{3}{*}{$\begin{array}{l}\text { Poly(DL-lactide-co- } \\
\text { glycolide) }\end{array}$} & $\begin{array}{l}\text { Ammonia } \\
\text { plasma/ } \\
\text { Collagen }\end{array}$ & $\begin{array}{l}\text { Mouse 3T3 } \\
\text { fibroblasts }\end{array}$ & Improved cell affinity & {$[70]$} \\
\hline & $\mathrm{TiO}_{2}$ & $\begin{array}{l}\text { Dermal } \\
\text { fibroblasts }\end{array}$ & $\begin{array}{l}\text { Improvement to surface } \\
\text { hydrophilicity and cell } \\
\text { adhesion }\end{array}$ & {$[74]$} \\
\hline & Laminin & Schwann cells & $\begin{array}{l}\text { Increased attachment and } \\
\text { affinity of cells to surface }\end{array}$ & {$[75]$} \\
\hline Polypropylene & $\begin{array}{l}\text { Ammonia } \\
\text { plasma }\end{array}$ & $\begin{array}{l}\text { Mesenchymal } \\
\text { stem cells }\end{array}$ & $\begin{array}{l}\text { Inhibition of type } \mathrm{X} \\
\text { collagen }\end{array}$ & {$[72]$} \\
\hline Poly(L-lactide) & $\mathrm{CO}_{2}$ plasma & $\begin{array}{l}\text { B65 glial cells } \\
\text { L929 fibroblast } \\
\text { cells }\end{array}$ & Increased cell adhesion & {$[73]$} \\
\hline Poly(glycolic acid) & $\begin{array}{l}\text { Surface } \\
\text { hydrolysis }\end{array}$ & $\begin{array}{l}\text { Vasular smooth } \\
\text { muscle cells }\end{array}$ & $\begin{array}{l}\text { Increased cell seeding } \\
\text { density and better cell } \\
\text { spreading }\end{array}$ & [79] \\
\hline
\end{tabular}

Table 1- List of synthetic polymers which have been surface modified to improve cellular affinity in a range of cell types. 
Despite these positive examples, paradoxically it is possible that surface modification of polymers with whole proteins may result in the adhered proteins being being unable to adopt the orientation required for cellular adhesion. As a solution to this, many groups have attempted to employ short cell recognition peptides instead. These short peptide sequences, found naturally in ECM proteins, bind to integrins on the surface of cells. The most commonly used peptides contain the tripeptide Arginyl-Glycyl-Aspartic acid (RGD) cell adhesion motif. Since the discovery in 1984 that the sequence could promote cell adhesion many methods have been developed for attachment of such peptides to a surface.[80] These methods have been extensively reviewed by Hersel et al. [81] Other peptide sequences such as Tyrosine-Isoleucine-Glycine-Serine-Arginine (YIGSR), a cell adhesion sequence in the ECM protein laminin, have also been shown to have useful endothelial cell mobility properties.[82] These peptides appear to act synergistically with the RGD sequence. Attachment of the YIGSR sequence to collagen scaffolds has previously been utilised in corneal tissue engineering to increase cell survival and proliferation.[83] Other studies have also investigated the response of adipose-derived stem cells to PCL with different attached laminin fragments.[78] The sequence Isoleucine-Lysine-Valanine-Alanine-Valanine (IKVAV) was found to significantly improve cell adherence when compared to other sequences. There have also been studies to compare the effect of linear and cyclic RGDcontaining peptides in osteoprogenitor cell culture.[84] Cyclic peptides are more resistant to proteolysis and can have higher binding affinities for integrin receptors compared to their linear counterparts. This behaviour may confer advantages for cell binding.

Besides the use of plasmas, proteins and peptides, other surface modifications have been shown to modulate the response of cells to a biomaterial surface. Surface hydrolysis of poly(glycolic acid) fibres was found to increase cell-seeding density of vascular smooth muscle cells and result in better spreading of cells across the polymer surface.[79] It has been found that incorporation of different functional groups on the surface of polymer scaffolds can control interactions with adsorbed proteins and subsequently cellular adhesion.[85] For example surface functional groups have been found to affect the adhesion, migration and differentiation of neural stem cells.[86] 


\section{Other biomaterial properties to consider}

It is not only the surface chemistry of a biomaterial which controls cellular behaviour, surface topography may also have a significant influence (Figure 2).[87] Basement membranes which support cellular growth within the body have a surface topology appropriate to their function. [88,89] The interaction of cells with fibres has been of interest ever since the successful use of carbon fibers in inducing tendon and ligament formation.[90] More recently, the texture and morphology of polymer fibers produced by electrospinning have been found to affect the shape and proliferation of mesenchymal stem cells. [91] Cellular responses to grooves and ridges have also been investigated.[92] However, it remains difficult to ascertain whether cells are reacting to topological or chemical cues. Experiments by Britland et al. [93] suggest that both types of cues may act synergistically. Thus biomaterials need to be engineered to mimic these natural membranes as closely as possible.[94] The influence of surface topology on cellular growth has been reviewed previously.[95] Studies have also been conducted to assess how material topography can be used to build 3D tissue structures including corneal stroma.[96] This approach was found to increase the functionality of tissue-engineered cellular sheets.

The mechanical properties of substrates also have an important role to play in creating an appropriate tissue engineering scaffold for cellular attachment and proliferation. Mechanical stiffness of materials has been shown to influence the differentiation of neural stem cells.[97] These properties are also important when considering the method of implanting biomaterials into the body. Materials based on poly( $N$-isopropylacrylamide) (PNiPAAM) exhibit a phase change at or around $37^{\circ} \mathrm{C}$ which is known as the Lower Critical Solution Temperature (LCST) of the material. Below this temperature, PNiPAAM gels are transparent and pliable while, above the LCST, the gels become more rigid and opaque. This results in a material which is easily injectable at room temperature while becoming a more rigid support at body temperature. Such materials have been shown to be capable of supporting cellular growth in vitro and have significant potential as thermally responsive tissue-engineering scaffolds.[98] Biomaterials based on peptides which can respond to other environmental stimuli such as $\mathrm{pH}$, temperature and light have also shown promise in the area of regenerative medicine. [99] 
In conclusion, routine clinical transplantation of RPE cells or indeed stem cells for retinal repair remains a distant prospect. Many basic cell biology questions need to be addressed prior to successful retinal transplantation. Not least among these is how cells can be transplanted most efficiently to sustain viability and functionality. Biomaterial scaffolds offer a novel transplantation strategy, with the ability to manipulate the extracellular environment both in vitro and following implantation. Biomaterial characteristics which afford the most appropriate degree of cell attachment, differentiation and maintenance of apposite function for individual organs including the eye are currently being elucidated.

Acknowledgements- We thank the Biomedical Imaging Unit, School of Medicine and the Science and Engineering Electron Microscopy Centre, School of Chemistry, University of Southampton for assistance with SEM.

Funding- Financial support was provided by National Institute Health Research, National Eye Research Centre, British Retinitis Pigmentosa Society and Foresight RP.

Licence for Publication- The Corresponding Author has the right to grant on behalf of all authors and does grant on behalf of all authors, an exclusive licence (or non exclusive for government employees) on a worldwide basis to the BMJ Publishing Group Ltd to permit this article (if accepted) to be published in BJO and any other BMJPGL products and sublicences such use and exploit all subsidiary rights, as set out in our licence (http://group.bmj.com/products/journals/instructions-for- authors/licence-forms).

\section{Competing Interests- None}




\section{Reference List}

1 Hartong DT, Berson EL, and Dryja TP. Retinitis pigmentosa. Lancet 2006;368:17951809.

2 Jager RD, Mieler WF, and Miller JW. Age-related macular degeneration. N.Engl.J.Med. 2008;358:2606-2617.

3 Acland GM, Aguirre GD, Bennett J et al. Long-term restoration of rod and cone vision by single dose rAAV-mediated gene transfer to the retina in a canine model of childhood blindness. Mol.Ther. 2005;12:1072-1082.

4 Bennicelli J, Wright JF, Komaromy A et al. Reversal of blindness in animal models of leber congenital amaurosis using optimized AAV2-mediated gene transfer. Mol.Ther. 2008;16:458-465.

5 Tschernutter M, Schlichtenbrede FC, Howe S et al. Long-term preservation of retinal function in the RCS rat model of retinitis pigmentosa following lentivirus-mediated gene therapy. Gene Ther. 2005;12:694-701.

6 Bainbridge JW, Smith AJ, Barker SS et al. Effect of gene therapy on visual function in Leber's congenital amaurosis. N.Engl.J.Med. 2008;358:2231-2239.

7 Hauswirth WW, Aleman TS, Kaushal S et al. Treatment of leber congenital amaurosis due to RPE65 mutations by ocular subretinal injection of adeno-associated virus gene vector: short-term results of a phase I trial. Hum.Gene Ther. 2008;19:979-990.

8 Maguire AM, Simonelli F, Pierce EA et al. Safety and efficacy of gene transfer for Leber's congenital amaurosis. N.Engl.J.Med. 2008;358:2240-2248.

9 Gias C, Jones M, Keegan D et al. Preservation of visual cortical function following retinal pigment epithelium transplantation in the RCS rat using optical imaging techniques. Eur.J.Neurosci. 2007;25:1940-1948.

10 Pinilla I, Cuenca N, Sauve Y et al. Preservation of outer retina and its synaptic connectivity following subretinal injections of human RPE cells in the Royal College of Surgeons rat. Exp.Eye Res. 2007;85:381-392.

11 Schraermeyer U, Kayatz P, Thumann G et al. Transplantation of iris pigment epithelium into the choroid slows down the degeneration of photoreceptors in the RCS rat. Graefes Arch.Clin.Exp.Ophthalmol. 2000;238:979-984.

12 Berger AS, Tezel TH, Del Priore LV et al. Photoreceptor transplantation in retinitis pigmentosa: short-term follow-up. Ophthalmology 2003;110:383-391.

13 Kaplan HJ, Tezel TH, Berger AS et al. Human photoreceptor transplantation in retinitis pigmentosa. A safety study. Arch.Ophthalmol. 1997;115:1168-1172.

14 Humayun MS, de Juan E Jr, del CM et al. Human neural retinal transplantation. Invest Ophthalmol.Vis.Sci. 2000;41:3100-3106. 
15 Radtke ND, Aramant RB, Seiler MJ et al. Vision change after sheet transplant of fetal retina with retinal pigment epithelium to a patient with retinitis pigmentosa. Arch.Ophthalmol. 2004;122:1159-1165.

16 Radtke ND, Aramant RB, Petry HM et al. Vision improvement in retinal degeneration patients by implantation of retina together with retinal pigment epithelium. Am.J.Ophthalmol. 2008;146:172-182.

17 Abe $\mathrm{T}$, Yoshida $\mathrm{M}$, Tomita $\mathrm{H}$ et al. Auto iris pigment epithelial cell transplantation in patients with age-related macular degeneration: short-term results. Tohoku J.Exp.Med. 2000;191:7-20.

18 Lappas A, Foerster AM, Weinberger AW et al. Translocation of iris pigment epithelium in patients with exudative age-related macular degeneration: long-term results. Graefes Arch.Clin.Exp.Ophthalmol. 2004;242:638-647.

19 Thumann G, Aisenbrey S, Schraermeyer U et al. Transplantation of autologous iris pigment epithelium after removal of choroidal neovascular membranes. Arch.Ophthalmol. 2000;118:1350-1355.

20 Chen FK, Uppal GS, MacLaren RE et al. Long-term visual and microperimetry outcomes following autologous retinal pigment epithelium choroid graft for neovascular age-related macular degeneration. Clin.Experiment.Ophthalmol. 2009;37:275-285.

21 Tezel TH, Del Priore LV, Berger AS et al. Adult retinal pigment epithelial transplantation in exudative age-related macular degeneration. Am.J.Ophthalmol. 2007; 143:584-595.

22 Treumer F, Bunse A, Klatt C et al. Autologous retinal pigment epithelium-choroid sheet transplantation in age related macular degeneration: morphological and functional results. Br.J.Ophthalmol. 2007;91:349-353.

23 MacLaren RE, Uppal GS, Balaggan KS et al. Autologous transplantation of the retinal pigment epithelium and choroid in the treatment of neovascular age-related macular degeneration. Ophthalmology 2007;114:561-570.

24 da Cruz L, Chen FK, Ahmado A et al. RPE transplantation and its role in retinal disease. Prog.Retin.Eye Res. 2007;26:598-635.

25 Mooney DJ and Vandenburgh H. Cell delivery mechanisms for tissue repair. Cell Stem Cell 2008;2:205-213.

26 Coles BL, Angenieux B, Inoue T et al. Facile isolation and the characterization of human retinal stem cells. Proc.Natl.Acad.Sci.U.S.A 2004;101:15772-15777.

27 Tropepe V, Chiasson BJ, Horsford DJ et al. Retinal Stem Cells in the Adult Mammalian Eye. Science 2000;287:2032-2036.

28 MacNeil A, Pearson RA, MacLaren RE et al. Comparative analysis of progenitor cells isolated from the iris, pars plana, and ciliary body of the adult porcine eye. Stem cells (Dayton, Ohio) 2007;25:2430-2438. 
29 Asami M, Sun G, Yamaguchi M et al. Multipotent cells from mammalian iris pigment epithelium. Dev.Biol. 2007;304:433-446.

30 Sun G, Asami M, Ohta $\mathrm{H}$ et al. Retinal stem/progenitor properties of iris pigment epithelial cells. Dev.Biol. 2006;289:243-252.

31 Fischer AJ and Reh TA. Muller glia are a potential source of neural regeneration in the postnatal chicken retina. Nat.Neurosci. 2001;4:247-252.

32 Limb GA, Salt TE, Munro PM et al. In vitro characterization of a spontaneously immortalized human Muller cell line (MIO-M1). Invest Ophthalmol.Vis.Sci. 2002;43:864-869.

33 Osakada F, Ooto S, Akagi T et al. Wnt signaling promotes regeneration in the retina of adult mammals. J.Neurosci. 2007;27:4210-4219.

34 Ohta K, Ito A, and Tanaka H. Neuronal stem/progenitor cells in the vertebrate eye. Dev.Growth Differ. 2008;50:253-259.

35 Limb GA and Daniels JT. Ocular regeneration by stem cells: present status and future prospects. Br.Med.Bull. 2008;85:47-61.

36 Osakada F, Ikeda $\mathrm{H}$, Mandai $\mathrm{M}$ et al. Toward the generation of rod and cone photoreceptors from mouse, monkey and human embryonic stem cells. Nat.Biotechnol. 2008;26:215-224.

37 Chacko DM, Das AV, Zhao X et al. Transplantation of ocular stem cells: the role of injury in incorporation and differentiation of grafted cells in the retina. Vision Res. 2003;43:937-946.

38 Buchholz DE, Hikita ST, Rowland TJ et al. Derivation of functional retinal pigmented epithelium from induced pluripotent stem cells. Stem cells (Dayton, Ohio) 2009;27:2427-2434.

39 Idelson M, Alper R, Obolensky A et al. Directed differentiation of human embryonic stem cells into functional retinal pigment epithelium cells. Cell Stem Cell 2009;5:396408 .

$40 \mathrm{Lu} \mathrm{B}$, Malcuit C, Wang S et al. Long-term safety and function of RPE from human embryonic stem cells in preclinical models of macular degeneration. Stem cells (Dayton, Ohio) 2009;27:2126-2135.

41 Carr AJ, Vugler AA, Hikita ST et al. Protective effects of human iPS-derived retinal pigment epithelium cell transplantation in the retinal dystrophic rat. PLoS.One. 2009;4:e8152-

42 Del Priore LV, Tezel TH, and Kaplan HJ. Maculoplasty for age-related macular degeneration: reengineering Bruch's membrane and the human macula. Prog.Retin.Eye Res. 2006;25:539-562. 
43 Tamiya S, Liu L, and Kaplan HJ. Epithelial-mesenchymal transition and proliferation of retinal pigment epithelial cells initiated upon loss of cell-cell contact. Invest Ophthalmol.Vis.Sci. 2010;51:2755-2763.

44 MacLaren RE and Pearson RA. Stem cell therapy and the retina. Eye 2007;21:13521359.

45 Djojosubroto M, Bollotte F, Wirapati $\mathrm{P}$ et al. Chromosomal number aberrations and transformation in adult mouse retinal stem cells in vitro. Invest Ophthalmol.Vis.Sci. 2009;50:5975-5987.

46 West EL, Pearson RA, MacLaren RE et al. Cell transplantation strategies for retinal repair. Prog.Brain Res. 2009;175:3-21.

47 Tucker BA, Redenti SM, Jiang C et al. The use of progenitor cell/biodegradable MMP2-PLGA polymer constructs to enhance cellular integration and retinal repopulation. Biomaterials 2010;31:9-19.

48 Streilein JW, Ma N, Wenkel $\mathrm{H}$ et al. Immunobiology and privilege of neuronal retina and pigment epithelium transplants. Vision Res. 2002;42:487-495.

49 Sheridan C, Williams R, and Grierson I. Basement membranes and artificial substrates in cell transplantation. Graefes Arch.Clin.Exp.Ophthalmol. 2004;242:68-75.

50 Binder S, Stanzel BV, Krebs I et al. Transplantation of the RPE in AMD. Prog.Retin.Eye Res. 2007;26:516-554.

51 Gullapalli VK, Sugino IK, Van PY et al. Impaired RPE survival on aged submacular human Bruch's membrane. Exp.Eye Res. 2005;80:235-248.

52 Tezel TH, Del Priore LV, and Kaplan HJ. Reengineering of aged Bruch's membrane to enhance retinal pigment epithelium repopulation. Invest Ophthalmol.Vis.Sci. 2004;45:3337-3348.

53 Thumann G, Schraermeyer U, Bartz-Schmidt KU et al. Descemet's membrane as membranous support in RPE/IPE transplantation. Curr.Eye Res. 1997;16:1236-1238.

54 Hartmann U, Sistani F, and Steinhorst UH. Human and porcine anterior lens capsule as support for growing and grafting retinal pigment epithelium and iris pigment epithelium. Graefes Arch.Clin.Exp.Ophthalmol. 1999;237:940-945.

55 Lee CJ, Fishman HA, and Bent SF. Spatial cues for the enhancement of retinal pigment epithelial cell function in potential transplants. Biomaterials 2007;28:2192-2201.

56 Capeans C, Pineiro A, Pardo M et al. Amniotic membrane as support for human retinal pigment epithelium (RPE) cell growth. Acta Ophthalmol.Scand. 2003;81:271-277.

57 Ohno-Matsui K, Mori K, Ichinose S et al. In vitro and in vivo characterization of iris pigment epithelial cells cultured on amniotic membranes. Mol.Vis. 2006;12:1022-1032. 
58 Tomita M, Lavik E, Klassen $\mathrm{H}$ et al. Biodegradable polymer composite grafts promote the survival and differentiation of retinal progenitor cells. Stem cells (Dayton, Ohio) 2005;23:1579-1588.

59 Atala A. Tissue engineering for bladder substitution. World J.Urol. 2000;18:364-370.

60 Shin K, Jayasuriya AC, and Kohn DH. Effect of ionic activity products on the structure and composition of mineral self assembled on three-dimensional poly(lactide-coglycolide) scaffolds. Journal of Biomedical Materials Research, Part A 2007;83A:1076-1086.

61 Tao S, Young C, Redenti S et al. Survival, migration and differentiation of retinal progenitor cells transplanted on micro-machined poly(methyl methacrylate) scaffolds to the subretinal space. Lab Chip. 2007;7:695-701.

62 Redenti S, Neeley WL, Rompani S et al. Engineering retinal progenitor cell and scrollable poly(glycerol-sebacate) composites for expansion and subretinal transplantation. Biomaterials 2009;30:3405-3414.

63 Redenti S, Tao S, Yang J et al. Retinal tissue engineering using mouse retinal progenitor cells and a novel biodegradable, thin-film poly(e-caprolactone) nanowire scaffold. Journal of Ocular Biology, Diseases, and Informatics 2008;1:19-29.

64 Tezcaner A, Bugra K, and Hasirci V. Retinal pigment epithelium cell culture on surface modified poly(hydroxybutyrate-co-hydroxyvalerate) thin films. Biomaterials 2003;24:4573-4583.

65 Williams RL, Krishna Y, Dixon S et al. Polyurethanes as potential substrates for subretinal retinal pigment epithelial cell transplantation. J.Mater.Sci.Mater.Med. 2005;16:1087-1092.

66 Krishna Y, Sheridan CM, Kent DL et al. Polydimethylsiloxane as a substrate for retinal pigment epithelial cell growth. Journal of Biomedical Materials Research, Part A 2007;80:669-678.

67 Thumann G, Viethen A, Gaebler A et al. The in vitro and in vivo behaviour of retinal pigment epithelial cells cultured on ultrathin collagen membranes. Biomaterials 2009;30:287-294.

68 Djordjevic I, Britcher LG, and Kumar S. Morphological and surface compositional changes in poly(lactide-co-glycolide) tissue engineering scaffolds upon radio frequency glow discharge plasma treatment. Applied Surface Science 2008;254:1929-1935.

69 Thissen H, Chang KY, Tebb TA et al. Synthetic biodegradable microparticles for articular cartilage tissue engineering. Journal of Biomedical Materials Research, Part A 2006;77:590-598.

70 Yang J, Bei J, and Wang S. Enhanced cell affinity of poly (D,L-lactide) by combining plasma treatment with collagen anchorage. Biomaterials 2002;23:2607-2614. 
71 Józwiak AB, Kielty CM, and Black R. Surface functionalization of polyurethane for the immobilization of bioactive moieties on tissue scaffolds. Journal of Materials Chemistry 2008;18:2240-2240.

72 Nelea V, Luo L, Demers CN et al. Selective inhibition of type X collagen expression in human mesenchymal stem cell differentiation on polymer substrates surface-modified by glow discharge plasma. Journal of Biomedical Materials Research, Part A 2005;75:216-223.

73 Khorasani MT, Mirzadeh H, and Irani S. Comparison of fibroblast and nerve cells response on plasma treated poly (L-lactide) surface. Journal of Applied Polymer Science 2009;112:3429-3435.

74 Ryu G, Yang W, Roh H et al. Plasma surface modification of poly (-lactic-co-glycolic acid) (65/35) film for tissue engineering. Surface and Coatings Technology 2005;193:60-64.

75 Huang YC, Huang CC, Huang YY et al. Surface modification and characterization of chitosan or PLGA membrane with laminin by chemical and oxygen plasma treatment for neural regeneration. J.Biomed.Mater.Res.A 2007;82:842-851.

76 Chen G, Okamura A, Sugiyama K et al. Surface modification of porous scaffolds with nanothick collagen layer by centrifugation and freeze-drying. Journal of Biomedical Materials Research, Part B Applied Biomaterials 2009;90:864-872.

77 Prabhakaran MP, Venugopal J, Chan CK et al. Surface modified electrospun nanofibrous scaffolds for nerve tissue engineering. Nanotechnology 2008;19:455102455102.

78 Santiago LY, Nowak RW, Peter Rubin J et al. Peptide-surface modification of poly(caprolactone) with laminin-derived sequences for adipose-derived stem cell applications. Biomaterials 2006;27:2962-2969.

79 Gao J, Niklason L, and Langer R. Surface hydrolysis of poly(glycolic acid) meshes increases the seeding density of vascular smooth muscle cells. Journal of biomedical materials research 1998;42:417-424.

80 Pierschbacher MD and Ruoslahti E. Cell attachment activity of fibronectin can be duplicated by small synthetic fragments of the molecule. Nature 1984;309:30-33.

81 Hersel U, Dahmen C, and Kessler H. RGD modified polymers: biomaterials for stimulated cell adhesion and beyond. Biomaterials 2003;24:4385-4415.

82 Fittkau MH, Zilla P, Bezuidenhout D et al. The selective modulation of endothelial cell mobility on RGD peptide containing surfaces by YIGSR peptides. Biomaterials 2005;26:167-174.

83 Duan XD, McLaughlin C, Griffith M et al. Biofunctionalization of collagen for improved biological response: Scaffolds for corneal tissue engineering. Biomaterials 2007;28:78-88. 
84 Verrier S, Pallu S, Bareille R et al. Function of linear and cyclic RGD-containing peptides in osteoprogenitor cells adhesion process. Biomaterials 2002;23:585-596.

85 Keselowsky BG, Collard DM, and García AJ. Surface chemistry modulates fibronectin conformation and directs integrin binding and specificity to control cell adhesion. Journal of Biomedical Materials Research, Part A 2003;66:247-259.

86 Ren YJ, Zhang H, Huang $\mathrm{H}$ et al. In vitro behavior of neural stem cells in response to different chemical functional groups. Biomaterials 2009;30:1036-1044.

87 Dunn GA and Brown AF. Alignment of fibroblasts on grooved surfaces described by a simple geometric transformation. J.Cell Sci. 1986;83:313-340.

88 Berthiaume F, Moghe PV, Toner M et al. Effect of extracellular matrix topology on cell structure, function, and physiological responsiveness: hepatocytes cultured in a sandwich configuration. FASEB J. 1996;10:1471-1484.

89 Abrams GA, Goodman SL, Nealey PF et al. Nanoscale topography of the basement membrane underlying the corneal epithelium of the rhesus macaque. Cell Tissue Res. 2000;299:39-46.

90 Jenkins DH, Forster IW, McKibbin B et al. Induction of tendon and ligament formation by carbon implants. J Bone Joint Surg Br 1977;59-B:53-57.

91 Moroni L, Licht R, de Boer J et al. Fiber diameter and texture of electrospun PEOT/PBT scaffolds influence human mesenchymal stem cell proliferation and morphology, and the release of incorporated compounds. Biomaterials 2006;27:49114922.

92 Clark P, Connolly P, Curtis AS et al. Topographical control of cell behaviour. I. Simple step cues. Development 1987;99:439-448.

93 Britland S, Perridge C, Denyer M et al. Morphogenetic guidance cues can interact synergistically and hierarchically in steering nerve cell growth. Experimental Biology Online 1997;1:1-15.

94 Han D and Gouma PI. Electrospun bioscaffolds that mimic the topology of extracellular matrix. Nanomedicine. 2006;2:37-41.

95 Curtis A and Wilkinson C. Topographical control of cells. Biomaterials 1997;18:15731583.

96 Guillemette MD, Cui B, Roy E et al. Surface topography induces 3D self-orientation of cells and extracellular matrix resulting in improved tissue function. Integrative Biology 2009;1:196-196.

97 Saha K, Keung AJ, Irwin EF et al. Substrate modulus directs neural stem cell behavior. Biophysical journal 2008;95:4426-4438.

98 Stile RA, Burghardt WR, and Healy KE. Synthesis and Characterization of Injectable Poly( $\mathrm{N}$-isopropylacrylamide)-Based Hydrogels That Support Tissue Formation in Vitro. Macromolecules 1999;32:7370-7379. 
99 Mart RJ, Osborne RD, Stevens MM et al. Peptide-based stimuli-responsive biomaterials. Soft Matter 2006;2:822-822.

100 Thomson HA, Treharne AJ, Walker P et al. Optimisation of polymer scaffolds for retinal pigment epithelium cell transplantation. Br.J.Ophthalmol. 2010; [Epubdoi:10.1136/bjo.2009.166728]

Figure 1- Image depicting attachment of a mature retinal pigment epithelium (ARPE-19) cell line to a laminin coated porous Poly(L-lactide) (PLLA) with Poly(DL-lactide-co-glycolide) (PLGA) (25\%:75\%) scaffold following 1 week in vitro. Immunocytochemical characterization was utilised to confirm retention of phenotype using an antibody directed against the RPE marker- retinal pigment epithelium-specific protein-65kDa (RPE 65) (A) Cell nuclei labelled in blue with 4',6-diamidino-2-phenylindole DAPI (B). Merged image (C). Scale bar- $13 \mu \mathrm{m} .[100]$

Figure 2- Scanning electron micrographs highlighting the influence of polymer blend on surface topography. A- blend of Poly(L-lactide) (PLLA) with Poly(DL-lactide-co-glycolide) (PLGA) (10\%:90\%) showing surface macropores $(20-70 \mu \mathrm{m})$. B- 90\%:10\% blend of PLLA:PLGA has surface pores $(10-20 \mu \mathrm{m})$ with smaller micropores below the surface, approximately ten fold smaller. Scale bar $10 \mu \mathrm{m}$, Original magnification 3000x. 
A

C

B 


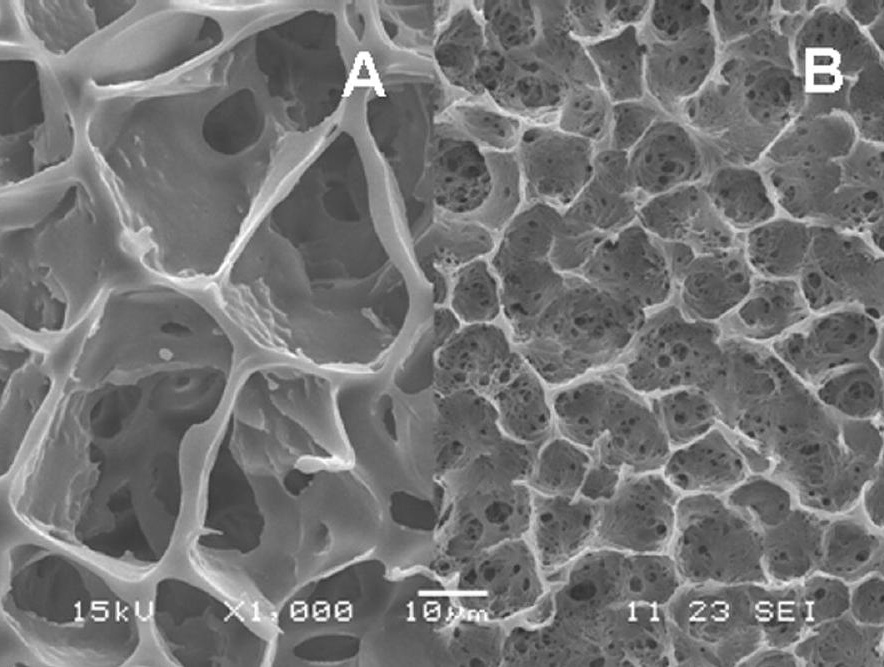

